\title{
KEMAMPUAN PEMECAHAN MASALAH MATEMATIS SISWA SEKOLAH DASAR
}

Tita Mulyati

\begin{abstract}
Abstrak
Pemecahan masalah merupakan salah satu kemampuan yang harus dikuasai siswa setelah belajar matematika. Kenyataannya, di SD, pembelajaran matematika yang mengembangkan kemampuan pemecahan masalah belum mendapat banyak perhatian dari guru-guru. Kurangnya perhatian guru terhadap pengembangan kemampuan pemecahan masalah dalam proses pembelajaran matematika mengakibatkan siswa kurang memiliki kemampuan pemecahan masalah. Kekurangan masalah non-rutin dalam buku sumber (teks) menjadi salah satu penyebabnya, selain itu guru terbiasa mengadopsi soal-soal yang terdapat pada buku sumber.Selain itu, pendekatan abstrak dengan metode ceramah dan pemberian tugas sangatlah dominan dari setiap kegiatan pembelajaran matematika di SD. Diperlukan pembelajaran yang mengintegrasikan pengetahuan, keterampilan, dan pemikiran yang kreatif serta lebih menekankan pada pengalaman dan keterlibatan siswa secara aktif dalam pemecahan masalah. Salah satu pembelajaran yang bisa dilakukan yaitu dengan menerapkan pendekatan pendidikan matematika realistik.
\end{abstract}

\section{Kata Kunci: Pemecahan Masalah, Matematis, Siswa SD}

\section{A. Pendahuluan}

Pembelajaran matematika di sekolah dasar tidak hanya ditujukan pada peningkatan kemampuan siswa dalam berhitung atau menerapkan rumus/ prosedur dalam menyelesaikan soal-soal rutin saja, tetapi juga pada peningkatan kemampuan siswa dalam pemecahan masalah, baik masalah matematika maupun masalah lain yang menggunakan matematika untuk memecahkannya.

Pemecahan masalah merupakan salah satu kemampuan yang harus dikuasai siswa setelah belajar matematika. Kemampuan ini sangat diperlukan siswa,terkait dengan kebutuhan siswa untuk memecahkan masalah yang dihadapinya dalam kehidupan sehari-hari dan mampu mengembangkan diri mereka sendiri.Oleh sebab itu, kemampuan pemecahan masalahperlu mendapatkan perhatian khusus dalam proses pembelajaran matematika dari jenjang pendidikan formal paling dasar, yaitu di SD. Pernyataan ini didukung antara lain oleh National Council of Supervisors of Mathematics (NCSM, 1977) bahwa "learning to solve problems is the principal reason for studying mathematics” dan National Council of Teacher 
of Mathematics (NCTM, 1980) bahwa problem solving must be the focus of the curriculum.

\section{B. Pemecahan Masalah Matematis}

Pemecahan masalah telah menjadi tema utama dalam penelitian dan kurikulum seluruh dunia (Torner, Schoenfeld, \& Reiss, 2007), termasuk di Indonesia.Dalam standar isi pada Permendiknas No. 22 Tahun 2006 dinyatakan bahwa kemampuan memecahkan masalah matematika yang meliputi kemampuan memahami masalah, merancang model matematika, menyelesaikan model, dan menafsirkan solusi yang diperoleh adalah salah satu dari tujuan mata pelajaran matematika. Selain itu, banyak penelitian yang telah dilakukan terkait dengan pengembangan kemampuan pemecahan masalah matematis melalui penerapan berbagai pendekatan dan model pembelajaran, di antaranya dilakukan oleh Ahmad (2005) dengan model pembelajaran berbasis masalah, Marzuki (2006) dengan pembelajaran kooperatif, Sugiman (2010) dengan pembelajaran matematika realistik, dan lain sebagainya.

Kenyataannya, di SD, pembelajaran matematika yang mengembangkan kemampuan pemecahan masalah belum mendapat banyak perhatian dari guruguru. Guru sering kali lebih menekankan pada penyampaian konten atau materi pelajaran dan algoritma untuk menyelesaikan soal daripada memberikan situasi yang menekankan pada penguasaan kemampuan pemecahan masalah dengan membiasakan memberi masalah-masalah non-rutin yang menuntut siswa untuk berpikir menggunakan pengetahuan yang telah dimiliki sebelumnya terkait dengan masalah yang mereka hadapi, yang akhirnya siswa dapat menemukan strategi untuk menyelesaikan masalah tersebut. Dengan demikian, tidak akan ada istilah siswa tidak bisa menyelesaikan soal karena 'lupa atau tidak tahu atau tidak ada rumusnya'. Hal ini bukan hanya terjadi di Indonesia, berdasarkan hasil penelitian di Belanda diketahui bahwa guru seringkali tidak menyediakan situasi bagi siswa yang dapat mengembangkan keterampilan pemecahan masalah dan sikap yang penting dalam menyelesaikan masalah non-rutin (Doorman, Drijvers, Dekker, Heuvel-Panhuizen, de Lange \& Wijers, 2007). 
Kurangnya perhatian guru terhadap pengembangan kemampuan pemecahan masalah dalam proses pembelajaran matematika mengakibatkan siswa kurang memiliki kemampuan pemecahan masalah. Hal ini ditunjukkan oleh hasil PISA tahun 2003 bahwa kemampuan siswa Indonesia pada domain pemecahan masalah, masih rendah.Walaupun hasil ini menggambarkan kemampuan matematika siswa SLTP yang berumur 15 tahun tetapi dapat dijadikan petunjuk kemampuan matematika siswa pada jenjang sebelumnya, yaitu Sekolah Dasar. Selain itu, hasil Monitoring dan Evaluasi PPPPTK Matematika (2007) dan PPPG Matematika tahun-tahun sebelumnya menunjukkan lebih dari 50\% guru SD menyatakan bahwa sebagian besar siswa mengalami kesulitan dalam menyelesaikan soal cerita (Marsudi, 2008). Meskipun soal cerita bisa jadi hanya perlu menerjemahkan dari kata-kata ke dalam kalimat matematika kemudian menerapkan satu atau lebih algoritma dan belum tentu merupakan masalah (problem) tetapi hal ini bisa menjadi gambaran bila siswa mengalami kesulitan dalam menyelesaikan soal cerita apalagi pada soal pemecahan masalah. Hasil penelitian Bocro dan Dapucto (2007) dalam menyelesaikan soal banyak siswa yang tidak mampu membuat solusi yang baik, mereka hanya mampu meniru cara yang guru berikan, banyak siswa yang kesulitan dalam menghadapi masalah terbuka, serta siswa terlihat senang ketika guru memberikan jawaban, sementara itu siswa sendiri tidak bersedia untuk mencari jawaban. Hal tersebut menunjukkan kurangnya ketekunan dari siswa karena tidak bertahan ketika mencoba untuk memecahkan masalah.

Kekurangan masalah non-rutin dalam buku sumber (teks) menjadi salah satu penyebabnya, selain itu guru terbiasa mengadopsi soal-soal yang terdapat pada buku sumber. Pemberian soal non-rutin merupakan salah satu cara agar kemampuan pemecahan masalah siswa SD dapat berkembang. Ruseffendi (1991) mengemukakan beberapa alasan pentingnya memberikan soal-soal pemecahan masalah kepada siswa, antara lain: 1) dapat menimbulkan keingintahuan, memotivasi, dan membantu berpikir kreatif; 2) di samping memiliki pengetahuan dan keterampilan berhitung, dan lain-lain, diisyaratkan adanya kemampuan untuk terampil membaca dan membuat pernyataan yang benar; 3) dapat menimbulkan jawaban yang asli, baru, khas, dan beraneka ragam, serta dapat menambah 
pengetahuan baru; 4) dapat meningkatkan aplikasi ilmu pengetahuan yang sudah diperoleh; 5) mengajak siswa memiliki prosedur pemecahan masalah, mampu membuat analisis dan sintesis, dan dituntut untuk membuat evaluasi terhadap hasil pemecahannya; dan 6) merupakan kegiatan penting bagi siswa yang melibatkan bukan saja satu bidang studi tetapi bila diperlukan mungkin bidang atau pelajaran lain, sehingga merangsang siswa menggunakan segala kemampuannya dalam menyelesaikan permasalahan dalam menghadapi kehidupannya kini maupun kelak di kemudian hari.

Terciptanya pembelajaran yang dapat mengembangkan kemampuan pemecahan masalah tidak terlepas dari materi yang akan dipelajari dan bagaimana cara menciptakan dan mengolah materi itu sehingga siswa dapat terlibat aktif mendayagunakan pikirannya membentuk konsep dalam proses pemecahan masalah. Hal tersebut menegaskan bahwa pembelajaran tidak hanya bergantung pada bagaimana guru mengajar tapi bagaimana guru mengkreasi.Oleh karena itu, diperlukan kemampuan guru dalam membuat soal-soal non-rutin dan kreativitasnya dalam memodifikasi soal rutin dalam buku teks menjadi soal nonrutin, serta mengembangkan bahan ajar pemecahan masalah untuk siswa yang digunakan dalam pembelajaran.Kemampuan tersebut penting juga dikuasai oleh mahasiswa PGSD, agar kelak saat mereka menjadi guru dapat melaksanakan pembelajaran dengan baik sehingga dapat meningkatkan kemampuan pemecahan masalah matematis dari siswa sekolah dasar.

Soal dikelompokkan menjadi soal rutin dan soal non-rutin.Oleh karena itu, tidak setiap soal dapat disebut masalah. Dalam konteks proses belajar matematika, yang dinamakan masalah adalah yang dikaitkan dengan materi belajar atau materi penugasan matematika masalah, dan bukan persoalan yang terkait dengan hambatan dalam belajar atau rendahnya hasil belajar yang diperoleh siswa dalam matematika. Sulit menentukan apakah suatu soal termasuk katagori masalah atau bukan.Hal itu dimungkinkan karena masalah bersifat relatif. Suatu masalah bagi seseorang belum tentu merupakan masalah bagi orang lain. Apabila soal yang dihadapi siswa adalah soal yang biasa ditemuinya sehingga ia hanya perlu menggunakan prosedur atau algoritma yang sering digunakan, maka soal tersebut 
merupakan soal rutin dan bukan merupakan masalah baginya, tetapi jika soal itu belum pernah ditemui sebelumnya dan ia memiliki pengetahuan yang cukup dan sesuai untuk menyelesaikannya maka soal itu disebut masalah. Ciri-ciri suatu soal disebut masalah, yaitu: menantang pikiran, tidak otomatis diketahui cara penyelesaiannya (non-rutin), dan bergantung pada individu yang menghadapinya.

Banyak definisi dari masalah yang dikemukakan para ahli, di antaranya: $a$ deviation from an expected standard of perform (Kepner \& Tregoe's dalam vanGundy, 2005); a gap between a current and a desired state of affairs - a gap between where you are where you would like to be (MacCrimmon \& Taylor dalam vanGundy, 2005); a situation that confronts the learner, that requires resolution, and for which the path to the answer is not immediately known (Posamentier dan Krulik, 2009), dan sebagainya. Berdasarkan pendapat-pendapat di atas dapat disimpulkan bahwa masalah merupakan kesenjangan antara keadaan saat ini dengan keadaan diinginkan yang sedang dihadapi seseorang dan butuh penyelesaian tetapi tidak bisa diselesaikan saat itu juga, dan seseorang akan menganggap itu masalah jika ia menyadarinya sehingga terdorong untuk memecahkannya.

Salah satu materi yang dipelajari di SD adalah pecahan, pembahasannya mengenai pengenalan dan pengerjaan operasi hitung dasar. Di kelas IV, materi pecahan yang dipelajari siswa terurai dalam 1 standar kompetensi, yaitu menggunakan pecahan dalam pemecahan masalah dan 5 kompetensi dasar, yaitu menjelaskan arti pecahan dan urutannya, menyederhanakan berbagai bentuk pecahan, menjumlahkan pecahan, mengurangkan pecahan, dan menyelesaikan masalah yang berkaitan dengan pecahan. Berikut pada Gambar 3.1 adalah contoh soal rutin materi pokok bilangan pecahan yang terdapat pada buku SD/MI Kelas IV (Mustaqim dan Astuty, 2008).Hanya dibutuhkan algoritma atau prosedur yang rutin untuk mengerjakan soal-soal tersebut. 


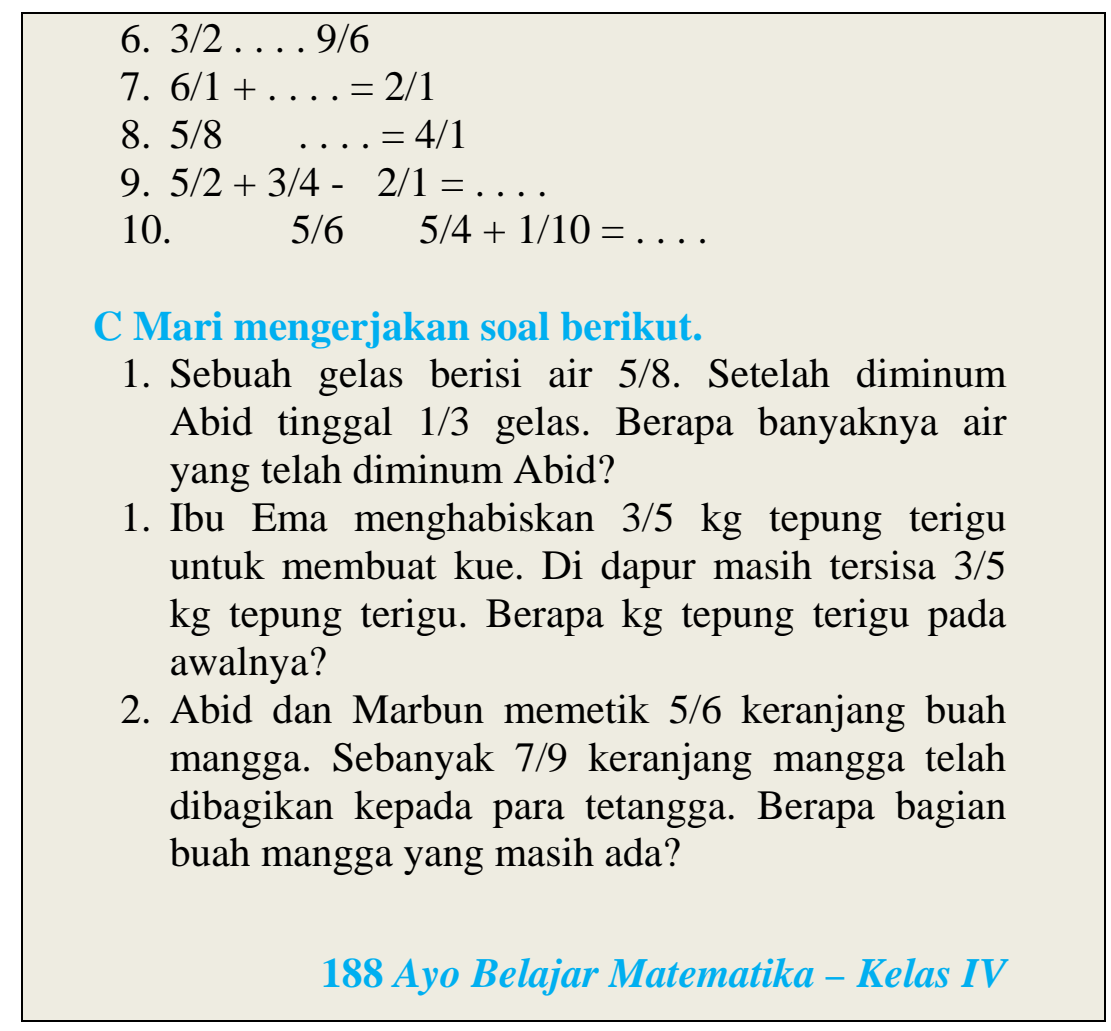

\section{Gambar 3.1}

Contoh Soal Rutin

Contoh masalah untuk kelas 3-4,

Ms. Perlman has an open field that she wants to mark into separate sections. She leaves one-half of the field for her three horses. Of the rest, $2 / 3$ is marked off for the turkeys to roam freely. The remainder lies fallow for this season. How much of the field lies fallow? (Posamentier dan Krulik, 2009)

Dalam menjawab soal di atas, siswa mungkin saja menjumlahkan 1/2 dan 2/3 dan hasilnya 7/6.Jelas ini keliru, karena 7/6 lebih besar dari keseluruhan ladang. Pengetahuan awal terkait masalah yang perlu dimiliki siswa adalah pengenalan pecahan bahwa pecahan pasti sebagian kecil dari sesuatu, 1/2 adalah satu bagian dari dua bagian yang sama, 2/3 adalah dua bagian dari tiga bagian yang sama. Bila pengerjaan siswa seperti yang dicontohkan di atas, artinya siswa belum memahami masalah sehingga siswa tidak bisa memahami apa yang diinginkan dari soal, yaitu 2/3 dari 1/2 bagian. 
Istilah pemecahan masalah mempunyai banyak perbedaan arti di setiap negara, tetapi saat ini pemecahan masalah telah menjadi tema utama dalam penelitian dan kurikulum di seluruh dunia sejak National Council of Supervisors of Mathematics (NCSM) pada tahun 1977 merumuskan bahwa belajar memecahkan masalah adalah alasan utama dalam mempelajari matematika. Terdapat banyak definisi tentang pemecahan masalah dalam matematika, di antaranya menurut Utari (2000) bahwa pemecahan masalah adalah suatu proses untuk mengatasi kesulitan yang ditemui untuk mencapai suatu tujuan yang diinginkan. Lenchner (dalam Wardhani, 2010), pemecahan masalah adalah proses untuk menyelesaikan masalah dengan menerapkan pengetahuan yang telah diperoleh sebelumnya ke dalam situasi baru yang belum dikenal. Oleh karenanya, dalam proses memecahkan masalah tentu saja pengetahuan awal atau pengetahuan yang telah diperoleh sebelumnya itu harus sesuai dengan masalah yang dihadapi, karena sebanyak apapun pengetahuan awal yang kita miliki, tidak bisa kita gunakan untuk memecahkan masalah jika tidak sesuai. Secara berbeda Polya (dalam Doorman, dkk., 2007) berpendapat bahwa solving a problem means finding a way out of a difficulty, a way around an obstacle, attaining an aim which was not immediately attainable. Suatu usaha mencari jalan ke luar dari suatu kesulitan, jalan di sekitar rintangan, mencapai suatu tujuan yang tidak segera dapat dicapai.Oleh karenanya, dalam memecahkan masalah tentu saja pengetahuan awal atau yang telah diperoleh sebelumnya itu harus sesuai dengan masalah yang dihadapi, karena sebanyak apapun pengetahuan awal yang kita miliki, tidak bisa kita gunakan untuk memecahkan masalah jika tidak sesuai.

Pemecahan masalah dapat dikatakan sebagai pendekatan dan tujuan yang ingin dicapai setelah belajar matematika (Hamzah, 2003). Jika pemecahan masalah sebagai pendekatan, maka asumsi-asumsi yang terdapat dalam pendekatan tersebut harus muncul dalam langkah-langkah pembelajaran yang akan dilakukan. Siswa dilatih untuk mampu memecahkan masalah dengan menggunakan langkah-langkah pemecahan masalah.Pemecahan masalah dipandang sebagai alat dalam memecahkan masalah yang dihadapi maupun dalam memahami atau menemukan suatu konsep matematika. Sedangkan pemecahan 
masalah sebagai tujuan yang ingin dicapai artinya setelah pembelajaran, siswa memiliki kemampuan-kemampuan yang terkait dengan indikator pemecahan masalah. Indikator pemecahan masalah yang termuat dalam Standar Isi (SI) pada Permendiknas Nomor 22 Tahun 2006, antara lain: memiliki kemampuan memahami masalah, merancang model matematika, menyelesaikan model, dan menafsirkan solusi yang diperoleh. Tidak jauh berbeda dengan itu, Utari (2010) menyatakan bahwa tujuannya adalah siswa mampu mengidentifikasi unsur yang diketahui, ditanyakan, dan kecukupan unsur; membuat model matematika; menerapkan strategi menyelesaikan masalah dalam/ di luar matematika, menjelaskan/ menginterpretasikan hasil; menyelesaikan model matematika dan masalah; serta menggunakan matematika secara bermakna. Kemampuan atau indikator-indikator tersebut sejalan dengan empat langkah pemecahan masalah dari Polya.

Perbedaan individu memiliki kaitan dengan aktivitas pemecahan masalah.Salah satunya adalah kemampuan akademis siswa.Kemampuan akademis setiap siswa berbeda, sehingga daya nalar dan respon mereka terhadap masalahpun berbeda, ada yang cepat dan ada pula yang lambat.Oleh karena itu, aktivitas pemecahan masalah membutuhkan kesabaran, tetapi aktivitas ini memungkinkan untuk bekerja secara sistematis dan jika seseorang bekerja secara perlahan banyak yang dapat berhasil.Selain itu, pemecahan masalah tidak harus merupakan aktivitas yang sulit atau tidak semua aktivitas yang sulit merupakan pemecahan masalah.Ini menunjukkan bahwa aktivitas pemecahan masalah dapat diberikan untuk semua siswa dan seharusnya diberikan untuk semua siswa.(Arcavi \& Friedlander, 2007).

Bila kita perhatikan model pembelajaran yang digunakan oleh kebanyakan guru di sekolah masih berpusat pada guru. Sesuai dengan yang diungkapkan Sobel dan Maletsky (2001:1-2) bahwa banyak sekali guru matematika yang menggunakan waktu pelajaran dengan kegiatan membahas tugas-tugas lalu, memberi pelajaran baru, kemudian memberi tugas kepada siswa.Selain itu, berdasarkan hasil diskusi dengan para peserta diklat guru pemandu matematika SD di PPPPTK Matematika (Sukayati, 2008) dikemukakan bahwa dalam 
pembelajaran matematika di SD, pendekatan abstrak dengan metode ceramah dan pemberian tugas sangatlah dominan dari setiap kegiatan pembelajaran, sehingga tidak mengherankan bila hasil pembelajaran matematika yang dikelolanya menjadi kurang maksimal, dan menjadi penyebab rendahnya kemampuan pemecahan masalah matematis siswa.

\section{Karakteristik Siswa SD dan Pembelajaran Kemampuan Pemecahan Masalah Matematis \\ Usia anak SD berada pada rentang 7-12 tahun. Berdasarkan hasil} penelitian Piaget diungkapkan bahwa perkembangan intelektual anak usia SD berada pada tahap operasional konkrit (Suherman, dkk.,2001). Pada tahap operasional konkrit ini siswa sudah mulai mengembangkan sistem berpikir logisnya, namun belum mampu berpikir deduktif formal.Selain itu, siswa belum mampu merumuskan semua alternatif jawaban yang mungkin dari sebuah masalah.

Pembelajaran matematika di SD tentunya harus disesuaikan dengan kebutuhan dan karakteristik siswa SD yang masih berada pada tahap operasional konkrit.Pada tahap ini anak dapat memahami operasi (logis) dengan bantuan benda-benda nyata, untuk memudahkan siswa dalam mempelajari materi matematika yang baru karena walaupun mereka telah dapat mengetahui simbolsimbol matematis tetapi belum dapat menghadapi hal-hal yang abstrak, maka dalam proses pembelajaran hendaknya diawali dalam konteks (situasi nyata), termasuk benda nyata sebagai penunjang keefektifan pembelajaran yang mengaitkan pengetahuan dan keterampilan yang telah mereka miliki dengan materi baru yang akan dipelajari. Secara bertahap siswa dibimbing untuk memahami materi matematika.

Menerapkan teori Bruner dalam pembelajaran merupakan salah satu cara agar pengetahuan yang didapat siswa lebih bermakna, yaitu diawali dengan memberikan situasi nyata atau benda konkrit untuk dimanipulasi oleh siswa (enaktif), kemudian mewujudkan pengetahuan dalam bentuk gambar (ikonik) yang menggambarkan kegiatan konkrit yang terdapat pada tahap enaktif, setelah itu memunculkan simbol-simbol abstrak (simbolik). Tetapi penggunaan benda 
konkrit bisa dihentikan bila representasi gambar sudah bisa mewakili atau dipahami siswa, dan representasi gambar pun bisa dihentikan pada saat representasi simbol sudah dipahami oleh siswa. Sebagai contoh, ketika mengajarkan penjumlahan kita memerlukan benda konkrit, memunculkan gambar, dan simbol, tetapi pada materi selanjutnya yaitu materi penjumlahan dengan bilangan yang lebih besar atau pengurangan bisa langsung ke representasi simbol, kecuali bila siswa memerlukannya, dan jangan sampai prosedur yang kita anggap bisa memudahkan siswa dalam memahami suatu konsep malah mengubah konsep itu sendiri.

Pelaksanaan pembelajaran pemecahan masalah di SD tidaklah semudah yang dibayangkan, mungkin saja lebih sulit untuk dilaksanakan karena pada rentang usia ini siswa belum mampu merumuskan semua alternatif jawaban yang mungkin dari sebuah masalah, masih berpikir secara holistik, integratif, dan konkrit, maka pembelajaran tentunya harus disesuaikan dengan kebutuhan dan karakteristik siswa, yaitu pembelajaran yang mengintegrasikan pengetahuan, keterampilan, dan pemikiran yang kreatif serta lebih menekankan pada pengalaman dan keterlibatan siswa secara aktif dalam pemecahan masalah. Oleh karena itu, ajarkan matematika dari hal yang konkrit menuju ke abstrak, dan hubungkan hal yang abstrak ke dalam kehidupan sehari-harinya.Terlebih untuk siswa SD yang merupakan masanya anak membentuk karakter dan biasa diibaratkan seperti bingkaiyang belum terbentuk.

Salah satu pembelajaran yang bisa dilakukan yaitu dengan menerapkan pendekatan pendidikan matematika realistik.Pendidikan matematika realistik sangat dipengaruhi oleh ide Freudenthal yakni matematika sebagai human activity atau suatu aktivitas manusia, bukan sekadar objek yang harus ditransfer dari guru ke siswa (Gravemeijer, 1991). Pembelajaran matematika berdasarkan pendekatan pendidikan matematika realistik merupakan pembelajaran yang bertitik tolak dari hal-hal yang nyata atau pernah dialami siswa, menekankan keterampilan proses yaitu memberikan kesempatan atau menciptakan peluang sehingga siswa aktif bermatematika (Sabandar, 2001).Hal tersebut diperkuat oleh pendapat Lakoff dan Núñez (2000:365) bahwa matematika manusia adalah diwujudkan, 
makadidasarkan pada pengalaman langsung di dunia.Oleh karena itu, pembelajaran matematika hendaknya menggambarkan aktivitas kehidupan manusia. Matematika tidak hanya berisi prosedur dan algoritma yang harus dipelajari siswa, tetapi suatu pembelajaran yang dapat dipelajari dengan cara mengerjakannya dan digunakan sebagai alat untuk menyelesaikan permasalahan.

Hal tersebut sejalan dengan pendapat Zulkardi (2001) yang menyatakan bahwa pembelajaran realistik matematika menekankan keterampilan 'process of doing mathematics' berdiskusi, berkolaborasi dan berargumentasi, dengan menggunakan suatu situasi nyata atau suatu konteks sebagai titik tolak dalam pembelajaran. Dengan pembelajaran ini siswa dapat menemukan sendiri strategi atau cara penyelesaian masalah baik secara individu atau secara berkelompok dan mengkomunikasikannya kepada kelas.

Sebagai suatu pendekatan pembelajaran, pendidikan matematika realistik memiliki prinsip dan karakteristik. Prinsip-prinsip tersebut antara lain: 1) penemuan terbimbing dan matematisasi berkelanjutan; dan 2) fenomenologi didaktik (Hadi, 2009). Penemuan terbimbing bisa berjalan dengan bantuan guru sebagai fasilitator sehingga siswa bisa menemukan kembali.Hal ini sejalan dengan teori dari Vigotsky tentang zona perkembangan proksimal.Matematisasi berkelanjutan berarti dimulai dari matematisasi horizontal menuju ke matematisasi vertikal.Matematisasi horisontal berproses mulai dari masalah realitas menuju ke lambang matematika sedangkan matematisasi vertikal merupakan proses yang terjadi di dalam sistem matematika itu sendiri. Setelah diberikan permasalahan sebagai titik awal, siswa bereksplorasi menemukan polapola untuk menemukan strategi penyelesaian masalah dengan arahan dari guru.

Sedangkan karakteristiknya, antara lain: 1) penggunaan konteks dalam eksplorasi fenomenologis; 2) penggunaan model untuk mengkonstruksi konsep (matematisasi horizontal dan vertikal); 3) pengunaan kreasi dan konstribusi siswa; 4) sifat aktif dan interaktif dalam proses pembelajaran; 5) kesalingterkaitan antara aspek-aspek atau unit-unit matematika (intertwinement) (Hadi, 2009). Prinsip dan karekteristik dari pendekatan pendidikan matematika realistik tersebut merupakan pedoman untuk penyusunan bahan ajar dan proses pelaksanaan pembelajaran di kelas. 
Prinsip dan karakteristik tersebut memiliki relevansi dengan peningkatan kemampuan pemecahan masalah siswa. Masalah nyata digunakan dalam pemecahan masalah dalam dua cara, pertama, sebagai sumber atau titik awal untuk mengembangkan konsep matematis; dan kedua, digunakan sebagai domain yang dapat kita gunakan konsep matematis dalam cara yang kita harapkan (Doorman, 2007). Dalam pembelajaran dengan pendekatan matematika realistik, pemberian masalah kontekstual di awal pembelajaran, bisa membantu siswa dalam menyelesaikan masalah dengan strategi yang mereka pahami, hal tersebut karena mereka bisa melihat keterkaitan materi yang sedang dipelajari dengan kehidupannya sehari-hari dan menggunakan pengetahuan awal yang sesuai dengan masalah yang dihadapi. Setiap siswa membuat model, kreasi dan memberikan konstribusi dalam pembelajaran dengan memunculkan strategistrategi pemecahan yang berbeda. Siswa aktif secara fisik ataupun mental dan berinteraktif dalam proses pembelajaran.

Penggunaan permasalahan kontekstual di awal pembelajaran digunakan untuk membangun konsep.Permasalahan atau soal bisa juga berasal dari siswa. Guru harus bisa memastikan kalau soal yang diberikan kepada siswa dan diselesaikan itu bermanfaat, sehingga soal harus didesain dengan benar. Sering kali kita kesulitan dalam membedakan konteks dalam pendekatan kontekstual dan pendekatan realistik.Dalam pembelajaran dengan pendekatan pendidikan matematika realistik, soal kontekstual tidak hanya kontekstual tapi harus benarbenar realistik. Penggunaan permasalahan kontekstual dipakai juga dalam pembelajaran biasa, perbedaannya dengan pendekatan realistik adalah pada pendekatan realistik permasalahan kontekstual digunakan sebagai titik awal untuk membangun pemahaman konsep dan penerapan dari konsep matematika itu sendiri, serta penyelesaian masalah bersifat terbuka karena siswa diarahkan untuk menemukan sendiri strategi penyelesaiannya, sehingga solusi dari siswa akan berbeda-beda. Sedangkan pada pembelajaran biasa penggunaan permasalahan kontekstual diberikan di akhir pembelajaran setelah guru memberi contoh dan menjelaskan prosedur dan algoritma sebagai suatu bentuk penerapan dari konsep yang telah dipelajari, dan penyelesaian masalahnya yang menekankan pada 
prosedur dan algoritma yang bersifat terbatas karena siswa hanya akan menyelesaikan masalah sesuai dengan yang telah diajarkan oleh guru kepadanya.

\section{Kesimpulan}

Pemecahan masalah merupakan salah satu kemampuan yang harus dikuasai siswa setelah belajar matematika. Kurangnya perhatian guru terhadap pengembangan kemampuan pemecahan masalah dalam proses pembelajaran matematika mengakibatkan siswa kurang memiliki kemampuan pemecahan masalah. Salah satu penyebab kurangnya perhatian guru terhadap pengembangan kemampuan pemecahan masalah dalam proses pembelajaran matematika adalah kurangnya masalah non-rutin dalam buku sumber (teks), selain itu guru terbiasa mengadopsi soal-soal yang terdapat pada buku sumber. Penggunaan pendekatan mekanistik dalam setiap pembelajaran, seperti pembelajaran yang lebih menekankan pada penyampaian konten pelajaran dan algoritma untuk menyelesaikan soal juga menjadi penyebab siswa kurang memiliki kemampuan pemecahan masalah.

Pembelajaran matematika di SD tentunya harus disesuaikan dengan kebutuhan dan karakteristik siswa SD yang masih berada pada tahap operasional konkrit, yaitu pembelajaran yang mengintegrasikan pengetahuan, keterampilan, dan pemikiran yang kreatif serta lebih menekankan pada pengalaman dan keterlibatan siswa secara aktif dalam pemecahan masalah. Salah satu pembelajaran yang bisa dilakukan yaitu dengan menerapkan pendekatan pendidikan matematika realistik, karena prinsip dan karakteristik tersebut memiliki relevansi dengan peningkatan kemampuan pemecahan masalah siswa. Mengubah kebiasaan dan cara pandang guru merupakan solusi untuk mengatasi rendahnya kemampuan pemecahan masalah matematis siswa.

\section{DAFTAR PUSTAKA}


Ahmad (2005).Kemampuan pemahaman dan pemecahan masalah matematika siswa SLTP dengan model pembelajaran berbasis masalah.Tesis pada SPs UPI.Tidak diterbitkan.

Arcavi \& Friedlander (2007).Curriculum developers and problem solving: the case of Israeli elementary school projects. ZDM Mathematics Education (2007) 39:355-364.DOI 10.1007/s11858-007-0050-3.

Badan Standardisasi Nasional Pendidikan (2006). Pedoman penyusunan kurikulum tingkat satuan pendidikan. Jakarta: Depdiknas.

Bocro, P. \& Dapunto, C. (2007). Problem solving in mathematics education in Italy:dreams and reality. ZDM Mathematics Education (2007) 39:383393.DOI 10.1007/s11858-007-0051-2.

Doorman, M., Drijvers, P., Dekker, T., Heuvel-Panhuizen, M., de Lange, J. \& Wijers, M.(2007). Problem solving as a challenge for mathematics education in The Netherlands.ZDM Mathematics Education (2007) 39:405-418.DOI 10.1007/s11858-007-0043-2.

Gravemeijer, K.P.E. (1991). RealisticMathematics Education in Primary School: An Instruction-theoretical on the use of manipulatives. Culemborg: Technipress.

Hadi, S. (2009).Standar PMRI untuk Penjamin Mutu.Bandung: IP-PMRI.

Hamzah (2003).Meningkatkan Kemampuan Memecahkan Masalah Matematika Siswa SLTP di Bandung melalui Pendekatan Pengajuan Masalah.Disertasi Doktor PPS UPI Bandung: tidak dipublikasikan.

Marzuki (2006).Implementasi pembelajaran koperatif (cooperative learning) tipe STAD dalam upaya meningkatkan kemampuan koneksi dan pemecahan masalah matematik siswa.Tesis pada SPs UPI.Tidak diterbitkan.

Mustaqim, B. \& Astuty, A. (2008).Ayo belajar matematika untuk SD dan MI kelas IV. Jakarta: Pusbuk Depdiknas.

National Council of Supervisors of Mathematics (NCSM) (1977)

National Council of Teacher of Mathematics (NCTM) (1980)

Posamentier, A. \& Krulik, S. (2009). Problem solving in mathematics grade 3-6. USA: Corwin.

Programme of International Student assesment (PISA) 2003. (2004). The PISA 2003 Assesment Framework. OECD 
Raharjo, M. (2008).Pembelajaran soal cerita berkait penjumlahan dan pengurangan di SD. Sleman: PPPPTK Matematika Depdiknas.

Ruseffendi, E. T. (1991). Penilaian pendidikan dan hasil belajar siswa khususnya dalam pengajaran matematika.Diktat Perkuliahan. IKIP Bandung: Tidak Dipublikasikan.

Sabandar, J. (2001). Aspek Konstektual dalam Soal Matematika dalam Realistics Mathematics Education.Makalah pada Seminar UPI Bandung : tidak dipublikasikan.

Sugiman (2010).Dampak pembelajaran matematika realistik terhadap peningkatan kemampuan pemecahan masalah dan keyakinan matematik siswa sekolah menengah pertama di kota Yogyakarta. Disertasi pada SPs UPI.Tidak diterbitkan.

Suherman, dkk.(2001). Strategi pembelajaran matematika kontemporer. Bandung: JICA.

Sukayati (2008).Pembelajaran operasi penjumlahan pecahan di Sd menggunakan berbagai media. Sleman: PPPPTK Matematika Depdiknas.

Torner, Schoenfeld, \& Reiss (2007).Problem solving in the mathematics classroom: the German perspective. ZDM Mathematics Education (2007) 39:431-441.DOI 10.1007/s11858-007-0040-5.

VanGundy, A. (2005). 101 activities for teaching creativity and problem solving.San Fransisco: Pfeiffer.

Wardhani, S. (2010).Pembelajaran kemampuan pemecahan masalah matematika di SD. Yogyakarta: PPPPTK Matematika Depdiknas.

Zulkardi (2001).Realistics Mathematics Education (RME), Teori, contoh Pembelajaran di Taman Belajar di Internet.Makalah Seminar RME FMIPA UPI Bandung : tidak dipublikasikan.

\section{BIODATA PENULIS}

Tita Mulyati dosen UPI Kampus Cibiru.Menyelesaikan S-2 pada Program Studi Pendidikan Matematika Sekolah Pascasarjana UPI. Saat ini sedang menempuh studi S-3 pada lembaga pendidikan yang sama. 